\title{
Mothers of a Nation: How Motherhood and Religion Intermingle in the Hebrew Bible
}

https://doi.org/10.1515/opth-2020-0012

Received September 30, 2019; accepted December 04, 2019

\begin{abstract}
Conception, pregnancy, childbirth, and the rearing of children are truly human experiences. But in religions and in their authoritative texts, these experiences are regularly utilized in metaphorical or symbolic language, or in narratives that tell of the origins of families or even peoples, of the relationship between individuals and groups or the relationship between humanity and the gods. Taking a closer look at the events surrounding childbirth and the time period of breastfeeding, it will be shown how literary texts from the Hebrew Bible go about intermingling motherhood and religion for the purpose of describing the origins of a nation.
\end{abstract}

Keywords: Hebrew Bible; mothers; childbirth; pregnancy; breastfeeding; theology

\section{Introduction}

Human families reflect a distinctly human understanding of conception, pregnancy, childbirth, and the rearing of children. These events influence and change the lives of individual mothers, fathers, siblings, as well as the lives of nuclear families. But in religions and in their authoritative texts, they are regularly utilized in metaphorical or symbolic language, or in narratives that tell of the origins of families or even peoples, of the relationship between individuals and groups or the relationship between humanity and the gods. In the latter case, religious texts can ascribe parental characteristics to the deities who care for humanity or frame the origin of humanity into the language of conception and childbirth. In those cases, motherhood and the bringing forth of children concerns more than a few individuals or a small or even an extended family.

In the Hebrew Bible, this is the case as well. Relationships between groups and peoples can be described as family relationships. God can take on both the role of the father who raises and teaches a child and of the mother who gives birth, cares and nurtures. Here, the Hebrew Bible allows glimpses into the way the beginning of life was experienced and interpreted by the authors who wrote these texts. And this is a point that must be emphasized when discussing religionification of motherhood and mothers' appropriation of religion. What the Hebrew Bible provides is a view of the ideas of conception, pregnancy, childbirth, and child-rearing as it was developed by the authors of this authoritative text, and not a description of the actual feelings and experiences of mothers and fathers, of children and siblings. The Hebrew Bible does not give us accurate descriptions of the circumstances of women and children two thousand or more years ago. One hears very little of the emotions after a failed attempt to become pregnant, or of the pleasures and discomforts experienced during pregnancy, or the pain of childbirth, or the hopes of the women bearing

*Corresponding author: Claudia D. Bergmann, Erfurt University, Erfurt, Germany; E-mail: claudia.bergmann@uni-erfurt.de 
children for their own futures and for those of their offspring, or the difficulties they might encounter when raising children. The perspectives of the mothers or of their close relations are almost lost in the Hebrew Bible. All that is left is the voice of the authors, who might have a certain and often distant knowledge about actual childbirth and motherhood, but who use these human experiences for their own literary purposes. In the end, it is the authors' pen or quill that shapes the biblical mothers into literary figures that appropriate the religious convictions of the biblical authors and act accordingly.

Taking a closer look at the events surrounding childbirth and the time period of breastfeeding, ${ }^{1}$ I will show how literary texts from the Hebrew Bible go about intermingling motherhood and religion for the purpose of describing the origins of a nation.

\section{Biblical Ideas of Conception}

When the Hebrew Bible discusses conception, pregnancy, and childbirth, it illustrates the influence of ancient Near Eastern literature. Biblical texts heavily draw on a much larger corpus of ancient Near Eastern metaphors that concern all aspects of motherhood and childbearing. The literary motifs and birth language are often couched in childbirth incantations, and they emphasize the involvement of gods such as Nisaba, Ninlil, Enlil, Utu, or Nintu/Ninhursaga as they deal with humanity in its individual and communal form. ${ }^{2}$ In the case of the Hebrew Bible, no such childbirth incantations exist. Rather, ideas of conception, pregnancy, childbirth and breast-feeding are located mainly in narratives as well as in poetic passages. These texts from the Hebrew Bible agree with literature from the ancient Near East in that they pay special attention to the involvement of the God of Israel in all stages of human life, especially at the points where life is created and brought forth. The divine interaction with the mothers described in the biblical text, however, can in no way be compared with the hands-on activities of the ancient Near Eastern gods and goddesses who were believed to be directly involved in all questions of fertility and birth. The God of Israel acts from afar and mainly through divine promises and announcements.

Cultural history provides the background for the ancient understanding of motherhood in all of its stages that was relevant for all ancient Near Eastern women and for women in ancient Israel, namely that, as Frymer-Kensky once stated, "biology was destiny"3.

The Hebrew Bible's metaphors for conception are often rather tactile and modeled on the home life of women or families or on the realms of agricultural production. The ability or inability of women to conceive can be pictured by the image of the open or locked door of the house, a motif known from the ancient Near East. ${ }^{4}$ In Psalm 139:13-15 conception is compared to the sowing of seeds; the embryo subsequently grows in

1 This article is based on two papers I presented on the occasion of several international workshops held at the Max-WeberKolleg of the University of Erfurt, Germany. They were part of the workshop series "Religionification of Motherhood and Mothers' Appropriation of Religion" organized by Giulia Pedrucci and others. The two workshops from which this contribution developed were entitled "Breastfeeding(s) and Religions: Normative Prescriptions and Individual Appropriation; A Cross-Cultural and Interdisciplinary Perspective from Antiquity to the Present” (on July 11-12, 2018) and "Pregnancies, Childbirths, and Religions: Rituals, Normative Perspectives, and Individual Appropriations; A Cross-Cultural and Interdisciplinary Perspective from Antiquity to the Present” (on January 31-February 1, 2019).

2 Cf. Kunz-Lübcke, "Schwangerschaft“. Also, Kunz, "Die Vorstellung von Zeugung und Schwangerschaft im antiken Israel“. For an introduction to ancient Near Eastern, Jewish, and Christian childbirth traditions, see Winter, Frau und Göttin; FrymerKensky, Motherprayer; Stol, Birth in Babylonia and the Bible. Also see Spitzer, Der zweiter Rosengarten, with an emphasis on the European and modern contexts.

3 Frymer-Kensky, Motherprayer, xvi: “... birth defined women and limited their roles in society ... women were expected to have children, women who did not give birth were considered 'barren' and unfortunate, and a woman who did not want to have children was somehow unnatural, unwomanly, devoid of the 'maternal instinct'. Society had a vested interest in women's wombs and sought to guard them by excluding women from occupations that might endanger the reproductive powers."

4 See, for example, Gen 16:2, Gen 20:18; 1 Sam 1:5-6. In the ancient Near East, see, for example Ligabue 51-53, VAT 8869, YOS 11 19, and possibly YBC 4603. For a summary on this and other childbirth motifs, see Bergmann, Childbirth as a Metaphor for Crisis, 9-56. Also, see Frymer-Kensky, Motherprayer, 19-22, on the motif of the locked door in the Hebrew Bible and the Talmud. 
the womb as a seed grows in the dark depths of the soil..$^{5}$ The fetus can also be understood as the product of a skilled divine knitter (Ps 139:13, Job 10:11) ${ }^{6}$ or of a potter (Job 10:9), or it can be described as solidifying or separating from fluid as curds would separate from whey (Job 10:10). In these images, conception is seen as a divine activity that turns fluids into solids and pieces of the natural world into a cultural product: out of seeds come plants, out of wool come threads and fabric, out of clay comes a vessel. The emphasis is on the deity making this process happen and initiating it regularly.

There is some evidence that the authors of the Hebrew Bible might have known that the behavior of the pregnant woman would affect the life and well-being of the fetus. This awareness of biological processes might have been based on observations of miscarriages in early pregnancy. In Judg 13:4-5, Manoah's wife is told not to drink alcohol or eat anything unclean in order to protect her pregnancy. The Hebrew Bible also mentions stillbirths ${ }^{7}$ and cases of death of newborn children ${ }^{8}$. It was part of the Hebrew Bible's war language that killing pregnant women was considered to be an atrocity committed mainly by the enemies of Israel. Other details that are connected to women's lives at the age when childbirth is possible, such as contraception or means to find out about the gender of the unborn child, both of which was discussed in ancient Near Eastern and Egyptian medical texts, did not find a place in the Hebrew Bible.

Stories of conception and subsequent birth can also be told in narratives, especially in the narratives about the ancestresses of Israel who regularly suffer from barrenness: Sarah conceives extraordinarily late in life (Gen 18:11-13); Rebecca is initially infertile (Gen 25:21); Rachel only bears two children after a long period of infertility (Gen 35). In many other cases, such as in the story of Tamar, conception is delayed, even though Tamar appears to be exceptionally fertile and becomes pregnant through a single sexual encounter with her father-in-law (Gen 38). In each and every case, though, it is God who changes the dire situation of barrenness and makes conception and pregnancy possible. ${ }^{9}$

God's involvement in conception and subsequent pregnancy can be portrayed as being so allencompassing ${ }^{10}$ that the human father of Israel's ancestors plays a minimal role, as is the case with Sarah and Abraham, who become the parents of Isaac. Gen 21:1-2 narrates the divine involvement in Sarah's becoming pregnant:

The Lord dealt with Sarah as he had said, and the Lord did for Sarah as he had promised. Sarah conceived and bore Abraham a son in his old age, at the time of which God had spoken to him. ${ }^{11}$

Both verses focus entirely on the mother: Sarah is visited by God; Sarah is the recipient of the divine deed promised previously; Sarah conceives; Sarah bears a son. Abraham appears almost as an addendum to the narrative. On the level of the text, he only becomes active once conception, pregnancy, and birth - activities during which God solely dealt with Sarah - are completed (Gen 21:3-5):

Abraham gave the name Isaac to his son whom Sarah bore him. And Abraham circumcised his son Isaac when he was eight days old, as God had commanded him. Abraham was a hundred years old when his son Isaac was born to him. ${ }^{12}$

Here, and especially in early Jewish texts that rewrite this passage or deal with it otherwise, Gudrun Holtz has shown convincingly that Abraham becomes more and more of an afterthought when texts describe the

5 Also cf. Deut 7:13, where conception and agricultural work are brought into a close connection. In Num 5:28, the woman is understood to be fertile ground that "is being sown with seed.” In Lev 12:2, woman is the one who brings forth the seed.

6 On weaving and knitting as metaphors for the endeavor of pregnancy, also in American folklore, see Frymer-Kensky, Motherprayer, 29-31.

7 Num 12:12, Ecc 6:3, Job 3:16 and others.

8 See, for example, Job 3:11.

9 Cf. Rachel's demand directed at Jacob to create children for her and Jacob's reply that only God can grant pregnancy in Gen 30:1-2. On infertility in biblical texts, see Garroway, Growing Up in Ancient Israel, 27-33.

10 See Gen 4:1 where Eve refers to having created a human being with YHWH, a detail that is often obscured by translations, see below, also cf. the New JPS Translation: "I have gained a male child with the help of the Lord."

11 New Revised Standard Version (=NRSV).

12 NRSV. 
involvement of God in this conception of Isaac. ${ }^{13}$ As conception occurs because of divine involvement and activity, the involvement of the human father becomes less and less important.

\section{Biblical Images for Pregnancy and Childbirth}

Archaeological evidence tell us that pregnancy and childbirth in ancient Israel were dangerous circumstances. In some areas, infant mortality approached $50 \%$. The female life expectancy could be as little as 30 years of age, 10 years less than the life expectancy for males. ${ }^{14}$

That pregnancy and childbirth were dangerous times is supported by the authoritative text of Judaism, the Hebrew Bible, although it never explicitly says so. The mothers of the Hebrew Bible are often said to have been supported by other women or midwives. ${ }^{15}$ One also reads of several ritual activities that were occasionally performed after a birth was completed: the cutting of the umbilical cord, a washing with water, the rubbing with salt, the clothing of the child by the attendants (Ez 16:4), the naming of the child by the parents ${ }^{16}$ and the circumcision of the infant boys on the eighth day after birth - all activities that, in modern days, belong to the realm of medicine rather than ritual. In addition, there were rituals that restored the young mothers to a ritually clean state ${ }^{17}$ and perhaps a ritual deposition of the placenta. ${ }^{18}$ This plethora of ritual activities shows that pregnancy and childbirth were times in the lives of individuals where rituals were urgently needed in order to prevent potential evil and misfortune from mothers and children.

In general, the Hebrew Bible does not dwell on descriptions of conception, pregnancy, and childbirth but often speaks in a rather formulaic language. Typical examples are "he knew his wife" or "she conceived and bore a son." Details about the mother's physical health and emotional state are rare, as the goal of the texts is not to describe actual pregnancies or occasions of childbirth but the early development of a people, for which the young ancestors are an examplar.

The pregnancy and childbirth of Eve is a case in point for this strategy. Eve's giving birth is described in formulaic language without discussing her actual feelings and her physical state. Two sons are born to her in apparent rapid succession and, according to the biblical text, without any problems or pain within less than two verses of the narrative (Gen 4:1-2a):

Now the man knew his wife Eve, and she conceived and bore Cain, saying, "I have produced a man with the help of the Lord.” Next she bore his brother Abel. ${ }^{19}$

Before these occurrences, however, God had promised her painful childbirth in Gen 3:16;20 but the same terminology is also applied to the agricultural work that Adam is supposed to do ${ }^{21}$ thus widening the view of labor (both the labor of childbirth and the labor in the field) to all of humanity (Gen 3:16-18):

13 Holtz, Jungfrauengeburt und Greisinnengeburt.

14 See Meyers, Discovering Eve, 95-110.

15 Cf. 1 Sam 4:20 and Gen 35:17; Gen 38:28; Ex 1:15-21. For an overview, see Finsterbusch, “Geburt (AT)”. Whether the women supporting the women giving birth in early Israel performed any magico-medical rituals is unknown, but there are certainly some hints about this in the Hebrew Bible. Tamar's firstborn, for example, is marked with the red thread, which might be an apotropaic means to keep danger away from him (Gen 38:28).

16 It appears that the naming of the child by the father was most common; cf. Gen 16:15; Gen 21:3; Hos 1:4.6.9. There are a few texts where the dying mothers name their sons, such as Rachel in Gen 35:18 or the nameless daughter-in-law of Eli in 1 Sam 4:21. About $50 \%$ of the biblical names bear theophoric elements, another hint as to the understood involvement of God in the processes of conception and childbirth.

17 Lev 12:2-5.

18 There is no reference to this in the Hebrew Bible, but later sources such as Tosefta Shabat 15:3 and Midrash Num 4:3 tell of the burial of the placenta.

19 NRSV.

20 English Standard Version (=ESV): “in pain”; NRSV: "in pain.”

21 ESV: "in pain”; NRSV: "in toil.” N.B.: Not all translations use the same terminology for the Hebrew term applied in both occasions. 
To the woman he said, "I will surely multiply your pain in childbearing; in pain you shall bring forth children. Your desire shall be for your husband, and he shall rule over you." And to Adam he said, "Because you have listened to the voice of your wife and have eaten of the tree of which I commanded you, 'You shall not eat of it,' cursed is the ground because of you; in pain you shall eat of it all the days of your life; thorns and thistles it shall bring forth for you; and you shall eat the plants of the field. ${ }^{22}$

What Eve might experience and feel is of little importance to the author of these texts. Important, however, is the description of the early history of the people that will soon develop into a nation and the description of the "painful" state of these early beginnings. ${ }^{23}$

the understood involvement of the deity in the birth of the ancestors of Israel is a very active one, just as ancient Near Eastern gods and goddesses were thought to have been actively involved in the birth of humanity. The birth of the two pairs of twins in the book of Genesis, both of which are in the family line of Abraham, shall serve as examples here. ${ }^{24}$

Abraham's son Isaac and his wife Rebecca achieve pregnancy only after a case of divine intervention. Then, Rebecca's pregnancy is riddled with difficulties (Gen 25:21-26):

And Isaac prayed to the Lord for his wife, because she was barren. And the Lord granted his prayer, and Rebekah his wife conceived. The children struggled together within her, and she said, "If it is thus, why is this happening to me?" So she went to inquire of the Lord. And the Lord said to her, "Two nations are in your womb, and two peoples from within you shall be divided; the one shall be stronger than the other, the older shall serve the younger." When her days to give birth were completed, behold, there were twins in her womb. The first came out red, all his body like a hairy cloak, so they called his name Esau. Afterward his brother came out with his hand holding Esau's heel, so his name was called Jacob. ${ }^{25}$

The conflict between Jacob and Esau narrated in Gen 25-27 finds its first expression in utero and before the children are even born, as Esau and Jacob kick each other and their mother. During the actual birth, there appears already to be a competition of who will be the firstborn. The question why this may be so is answered by divine oracular poetry that puts all of these events into the context of the history of Israel. It is not only the children that fight in Rebecca's uterus, but the conflict foreshadows the conflict between two peoples, as the biblical text tells the reader. Here, one does not have to read between the lines in order to realize that the birth of Esau and Jacob is not narrated for the purpose of describing their early beginnings or the childbirth event experienced by the ancestress Rebecca, but for the purpose of describing the birth of a nation.

A son of Jacob, Judah, is involved in another case of difficult conception, pregnancy, and labor in the Hebrew Bible. This brings the difficult childbirth motif into the third generation within the history of the family of Jacob involving Rebecca at the birth of Jacob himself, Rachel at the birth of one of Jacob's favorite sons, and Tamar, the companion of Judah, the fourth son of Jacob born into the family by Leah. ${ }^{26}$ In a complicated case of levirate marriage, Tamar conceives by her father-in-law, Judah, and bears twins named Perez and Zerah, who continue the line of Jacob further into the future ${ }^{27}$ (Gen 38:27-30):

When the time of her delivery came, there were twins in her womb. While she was in labor, one put out a hand; and the midwife took and bound on his hand a crimson thread, saying, "This one came out first." But just then he drew back his hand, and out came his brother; and she said, "What a breach you have made for yourself!" Therefore he was named Perez. Afterward his brother came out with the crimson thread on his hand; and he was named Zerah. ${ }^{28}$

22 ESV. It is often debated how this sentence needs to be translated, see Meyers, Discovering Eve, 95-110.

23 Details of the feelings of women during pregnancy and childbirth only become important in the Hebrew Bible when they are applied as a metaphor to describe God or men in personal, historical, or universal crises. In Isa 42:14, for example, YHWH gasps and pants like a woman in childbirth before becoming a warrior. Jeremiah applies the "pain" and "anguish" of labor to men hearing the news of a coming war (Jer 6:24, Jer 49:24, and Jer 50:43). For an overview, see Bergmann, Childbirth as a Metaphor for Crisis.

24 Cf. Bergmann, “Turning Birth into Theology”, 17-34. Also see Salm, Juda und Tamar; Garroway, Growing Up in Ancient Israel, 68-70. 25 ESV.

26 On the importance of mothers in the genealogy of Jacob’s sons, see Smith, The Role of Mothers in the Genealogical Lists of Jacob's Sons.

27 N.B.: the ancient author calls Tamar "righteous," which is the only such naming of a woman in the Hebrew Bible. 28 NRSV. 
The difficult childbirth narratives that are located in the ancestral stories of the book of Genesis are clustered in the family history of Jacob. It appears that the difficulties surrounding the births of these important ancestors only increase as time passes. While Sarah "only" battles infertility and conceives late in life, the next generation represented by Rebecca experiences infertility, a difficult pregnancy, and a difficult birth. Yet, one generation onwards, Jacob’s wives experience infertility (Rachel), delayed (Rachel) and unusual conception (Leah), and even a case of difficult childbirth resulting in the death of the mother (Rachel). One more generation down the family tree, Jacob's son Judah impregnates his son's widow Tamar, which results in a difficult childbirth event. With this worsening of circumstances, the narrator in the book of Genesis intends to show that the people Israel go through the early stages of their lives with great difficulty. The difficulties involved in the (imagined) birth of the early ancestors and the "birth" of this people grow in number and severity as each generation passes. As a result of this, the ancient authors would like to convey, God's involvement in overcoming these difficulties must have increased accordingly.

Occasionally, human motherhood in the Hebrew Bible can be connected to the behavior of a female trickster, as mothers sometimes promote one son over another or use unusual means to achieve pregnancy. This is the case for Rebecca, who favors Jacob over Esau even though he is the second born and helps him to gain his father's blessing. This is also the case for Tamar, who uses unusual means to become pregnant. It appears that the Hebrew Bible attributes to women the right to be a mother, to have offspring, and to be cared for by her children in old age. In that sense, there is nothing uniquely female about mothers in the Hebrew Bible. ${ }^{29}$ In the end, all functions of the female human body, including conception, pregnancy, childbirth, and the ability to rear children, are attributed to the graceful attention of the God of Israel, who may and will open or close wombs. Even the actions of mothers who favor one son over the other lead to the advancement of Israel, or, to frame it in theological terms, show that the God of Israel is in control of all of humanity, including mothers and their actions.

This strategy is not limited to the level of the narratives themselves. There is also much evidence that the terminology used in childbirth narratives points the reader not to individual or historical births but to events in the history of Israel. A few examples shall suffice here.

The most common term used in the narratives of difficult births is "he came out," in Hebrew, yatsa. ${ }^{30}$ Isaac and Rebecca's twins Jacob and Esau "come out” in Gen 25:25-26. Tamar and Judah's twins are said to "come out" no less than three times, in Gen 38:28, 29, and 30. But, most importantly, yatsa is also the Hebrew Bible's technical term for the exodus event. It refers to the God YHWH, who can "go out" in battle in order to liberate (Ex 11:4.89), to Moses and Aaron who call for the "going out" of the people (Ex 12:31), or to the action of "having come/coming out of Egypt," which becomes a standard phrase in the book of Exodus and beyond. ${ }^{31}$ In Isa 42:13-14, when God "goes forth" like a warrior and his behavior resembles that of women giving birth, yatsa and birthing language even appear in the same paragraph. ${ }^{32}$ The theological message of this intertextual terminological connection is: As Israel "came out" of Egypt, the forefathers of Israel "came out" of their mothers' wombs. Giving birth to these important ancestors thus parallels the Exodus event: from darkness into light, from a restricted space into a large space, from a restricted existence into fullness of life. The mothers of these children actually are seen as the mothers of the nation.

29 On this subject, also see Frymer-Kensky, Studies in Bible and Feminist Criticism, 187: "Israel actively promotes the nuclear family, and was determinedly pronatalistic. Both the biblical male characters in the authors of the stories clearly believed in the necessity for close peer-bonding and the rearing of children. These beliefs are completely in accord with the needs of early Israelite society.... It is clear that Western categories of aggressive/submissive and active/passive simply do not apply. Women in the Bible pursue their goals as actively as men. They have certain techniques and strategies at their disposal; they can use their access to food to set the mood and so influence people; they can use their powers of persuasion through reason, rhetoric and persistence (nagging); and they can trick and deceive when they cannot persuade. None of this is different from the strategies that men outside the power structure could be expected to use. They are all methods of indirect power, used by people who cannot take direct action: women, and subordinate men. Strategies and powers that are normally associated with women in our culture are conspicuously absent from the Bible.”

30 Cf. Preuss, “Yatsa”, VI: 225-250.

31 Examples are Ex 19:1, Num 1:1 etc.

32 On Isa 42, cf. Bergmann, “'Like a Warrior’ and 'Like a Woman Giving Birth”; Pardes, “The Biography of Ancient Israel”. 
The same case could be made for the terms derived from the root qashar "to bind (on)," which only occurs about sixty times in the Hebrew Bible. ${ }^{33}$ It is used in connection to the noun shani in Jos 2:18-21, when the God-fearing stranger Rahab ties a scarlet ribbon unto her window in order to mark her house as a safe one, and in the abovementioned Gen 38:28, when the midwife ties a scarlet ribbon as a sign that marks the firstborn among twins:

(Jos 2:18-21): Behold, when we come into the land, you shall tie this scarlet cord in the window through which you let us down, and you shall gather into your house your father and mother, your brothers, and all your father's household. Then if anyone goes out of the doors of your house into the street, his blood shall be on his own head, and we shall be guiltless. But if a hand is laid on anyone who is with you in the house, his blood shall be on our head. But if you tell this business of ours, then we shall be guiltless with respect to your oath that you have made us swear." And she said, "According to your words, so be it." Then she sent them away, and they departed. And she tied the scarlet cord in the window. ${ }^{34}$

(Gen 38:28): And when she was in labor, one put out a hand, and the midwife took and tied a scarlet thread on his hand, saying, "This one came out first." 35

Both of the instances that on the surface level seem to describe individual and historical events actually deal with theological reflections on the expansion of Israel: Tamar delivers two children and thus brings the family of Abraham, that is, the family of Jacob into a new generation; and Rahab delivers or saves, that is, the whole of Israel as they are fulfilling a divine promise and enter the land when history continues. ${ }^{36}$ The scarlet thread tied around the hand of an Israelite being delivered by his mother, and the one around the window of a woman who is a deliverer to Israel ties the stories of Tamar and Rahab together on both a terminological and a theological level. ${ }^{37}$

\section{Biblical Ideas of Breastfeeding}

From the ancient Near Eastern narratives, it is known that breastfeeding in the ancient cultures surrounding the Mediterranean took place for two or three years, extra-biblical evidence from the second century BCE such as in 2 Macc 7:27 supports the evidence gained from ancient Near Eastern texts. Wet-nursing was very common apparently, most often done by professional wet nurses, who were remunerated for the services and given additional rations of barley, oil, and wool. ${ }^{38}$ Ancient Near Eastern documents occasionally report cases were wet nurses would have liked to have kept the child after they had finished their breastfeeding obligations. ${ }^{39}$ Ancient Near Eastern documents also report of the special bond formed through wet-nursing,

33 Cf. Conrad, “Kashar”, XIII: 196-201.

34 ESV.

35 ESV.

36 Cf. Frymer, Kensky. In the Wake of the Goddesses, 36: "It is not surprising to find Rahab acting as 'midwife' of the embryonic Israel.... God promises to be with Joshua as with Moses (Josh. 1:5); flint knives are used in circumcisions (Josh. 5:2-3); Joshua and Moses-and only they-are told to remove their shoes because they stand on holy ground (Josh. 5:15); and the people cross the Jordan on dry land as they had crossed the Red Sea. The narrator heightens the parallel between Rahab and the Exodus story by using the relatively rare word for 'hide,' șNewpn, when she conceals the two Israelites under the flax ... Rahab hides the Israelites spies just as Moses' mother hid the baby. The women of the Exodus have found their successor."

37 In the history of interpretation, both Tamar and Rahab are often seen as disreputable women or foreigners, cf. the references to Tamar, Rahab, Ruth, and Bathsheba in Mt 1 of the New Testament. More examples of the terminological similarities between the birth narratives and the history of Israel can be found in Bergmann, “Turning Birth into Theology". Also see Binder, "Geburt II (religionsgeschichtlich)", 66, who suggests that the red threat is a ancient magical symbol that is supposed to bring protection: "vordergründig erscheint der rote Faden als Erkennungsmal für die Erstgeborenen, dahinter steht jedoch sicher alter Aberglaube; denn rot ist die Unterweltsfarbe und Farbe der Rechtsprechung, der rote Faden ein Unterweltsrequisit, gleichsam ein Amulett zur Abwendung von Schaden zur Übertragung von Lebensenergien.”

38 Stol, Birth in Babylonia and the Bible, 181-182.

39 Examples in Stol, Birth in Babylonia and the Bible, 186. 
as two people who had been nursed by the same woman feel connected even as adults. Occasionally, there is evidence that the wet nurse stayed in the service of the family, taking care of the young child even after nursing had finished..$^{40}$

As was the case with the biblical ideas of conception, pregnancy, and childbirth, the Hebrew Bible takes up the topic of breastfeeding ${ }^{41}$ by combining a truly human and often emotional experience with theological thinking. This physical act performed by mothers or wet nurses ensures the survival of an infant, but the Hebrew Bible frequently understands it in a symbolical manner. In those cases, it equals acts of kindness and care as well as acts of ensuring the survival of males in cases of danger.

It also appears that breastfeeding a child is understood to transfer ethnicity and status upon it. This might be the reason why Sarah's ability to breastfeed is emphasized by the biblical text. The younger slave Hagar, who also lived in the household of Abraham at the time, would have been the logical choice for breastfeeding Isaac. If she would have done so, she would have transferred not only her personal influence but possibly also her ethnicity upon him. For that reason, the biblical text makes sure that Sarah is mentioned as the one breastfeeding the ancestor of Israel and doing so for a rather long time so that Isaac's heritage could not have been questioned in any way. ${ }^{42}$

In the Hebrew Bible, breastfeeding is rarely ever connected to prominent childbirth narratives such as in the books of Genesis. The narratives do not mention that Rebecca or Tamar nurse their twin sons, Rachel does not appear to nurse either. Only Sarah's son Isaac was definitely nursed, as Gen 21:7-8 reports that Abraham initiated a festival on the occasion of his weaning:

And she said, "Who would have said to Abraham that Sarah would nurse children? Yet I have borne him a son in his old age.” And the child grew, and was weaned. And Abraham made a great feast on the day that Isaac was weaned. ${ }^{43}$

This feast occurs on the occasion of the rite of passage both for Isaac and for Sarah. ${ }^{44}$ It seems that after the ritual, Sarah again becomes more active in the life of the household of Abraham, which is shown in a particularly negative way when it comes to the treatment of Hagar. Additional information, however, is not provided by any of these narratives, and it again appears that the Hebrew Bible does not pay much attention to breastfeeding from the perspective of individual women and individual children. Again, this natural act of rearing one's child by breastfeeding is put in the literary context of God caring for God's people, thus ensuring their survival and their healthy growing up as a nation.

In the Hebrew Bible, breastfeeding or wet-nursing are regularly used as literary motifs that occur when important changes take place such as changes on a personal level and within a family ${ }^{45}$ or even within a community. In the latter case, breastfeeding narratives occur in times of political changes and inaugurate a reversal of circumstances for the people involved. Often, wet nurses take on a major role in these narratives, so much so that one can almost speak of a literary motif of the wet nurse saving the child from danger.

There are three instances in the Hebrew Bible where wet nurses (or a wet nurse who is actually the mother of the child) save important male children from certain death, thus continuing the existence of the

40 Stol, Birth in Babylonia and the Bible, 190-192. On the idea of wet-nursing in 18th-century France, see Hrdy, Mother Nature. 41 On breastfeeding in general, see Maher, The Anthropology of Breast-Feeding. More general information can be found in Fildes, Wet-Nursing. For breastfeeding in the Hebrew Bible and the ancient Near East, also see Marsman, Women in Ugarit and Israel; Gruber, "Breast-Feeding Practices”. For the image of breastfeeding in later Jewish mysticism, see Haskel, Suckling at my Mother's Breast.

42 Chapman, "Oh that you were like a brother to me". Another example is that of Moses, see below.

43 ESV.

44 Also cf. the rite of passage connected to the end of the breastfeeding period narrated in connection with Hannah and her son in 1 Sam 1:22-24. On Hannah in the Hebrew Bible and the Talmud, also see Frymer-Kensky, Motherprayer, 9-11.

45 Sarah and Isaac, Hannah and Samuel. Also cf. the breastfeeding relationship between Rebecca and her wet nurse Deborah in Gen 24:59 (also refer to Gen 35:8) that appears to form a bond that is carried into early adulthood when Rebecca experiences a rite of passage. 
nation or of the monarchy of Israel. These acts are instances of resistance against higher powers on the level of the state. ${ }^{46}$

In Ex 2:2-10, several women work together in a conspiracy to save the child Moses: the mother of Moses, who acts as a wet nurse; the sister of Moses; and Pharaoh's daughter, who both agrees to this act of resistance and also pays an Israelite woman to nurse the baby that will grow up in her house:

The woman conceived and bore a son, and when she saw that he was a fine child, she hid him three months. When she could hide him no longer, she took for him a basket made of bulrushes and daubed it with bitumen and pitch. She put the child in it and placed it among the reeds by the river bank. ${ }^{47}$ And his sister stood at a distance to know what would be done to him. Now the daughter of Pharaoh came down to bathe at the river, while her young women walked beside the river. She saw the basket among the reeds and sent her servant woman, and she took it. When she opened it, she saw the child, and behold, the baby was crying. She took pity on him and said, "This is one of the Hebrews' children." Then his sister said to Pharaoh's daughter, "Shall I go and call you a nurse from the Hebrew women to nurse the child for you?” And Pharaoh's daughter said to her, "Go." So the girl went and called the child's mother. And Pharaoh's daughter said to her, "Take this child away and nurse him for me, and I will give you your wages." So the woman took the child and nursed him. When the child grew older, she brought him to Pharaoh's daughter, and he became her son. She named him Moses, "Because," she said, "I drew him out of the water." 48

Two additional women are connected to the saving act by the larger context. The midwives Shiphrah and Puah, notably the only two named women in this narrative, ${ }^{49}$ are said to disobey the Pharaoh's direct orders to kill all male Hebrew children (Gen 1:15-21):

Then the king of Egypt said to the Hebrew midwives, one of whom was named Shiphrah and the other Puah, "When you serve as midwife to the Hebrew women and see them on the birthstool, if it is a son, you shall kill him, but if it is a daughter, she shall live." But the midwives feared God and did not do as the king of Egypt commanded them, but let the male children live. So the king of Egypt called the midwives and said to them, "Why have you done this, and let the male children live?” The midwives said to Pharaoh, "Because the Hebrew women are not like the Egyptian women, for they are vigorous and give birth before the midwife comes to them." So God dealt well with the midwives. And the people multiplied and grew very strong. And because the midwives feared God, he gave them families. ${ }^{50}$

As Gale A. Yee points out, Exod 2 is “an example of resistance literature during the Persian period to support anti-colonial resistance within the Jewish community in Jehud against Persian control." ${ }^{51}$ Apparently, the biblical text wanted to portray Israel as a marginalized people among the Egyptians and used marginalized individuals without any power within the Egyptian state or even within the Hebrew community - slaves, midwives, and wet nurses - in order to symbolize the people. As the unnamed mother saves her son by this act of political resistance, the survival of the future savior of the people Israel is guaranteed. The text thus provides hope for a generation of readers much removed from the imagined time of the narrative that salvation for the entire people is also possible during their lifetimes. In addition, the legitimacy of Moses is ensured, as it is his actual mother who serves as a wet nurse and thus transfers her Levitical heritage into her son, who is later understood as the "eponymous ancestor of the Levitical priests." 52

46 Ruddick, Maternal Thinking, would argue that these actions are examples of motherhood, cf. pg. 40: “... a mother is a person who takes on responsibility for children's lives and for whom providing child care is a significant part of her or his working life.... Although most mothers have been and are women, mothering is potentially work for men and women.” Also see pg. xi: "in my more particularized conception, mothers are people who see children as "demanding” protection, nurturance, and training; they attempt to respond to children's demands with care and respect rather than indifference or assault."

47 Cf. the ancient Near Eastern boat motif that symbolizes pregnancy and the process of childbirth, for a summary see Bergmann, Childbirth as a Metaphor for Crisis, 65-66. In the Akkadian Sargon-legend, the king is exposed to the waters of the river in much the same way as is Moses in Exod 2.

48 ESV. For a discussion of the Birth-of-a-Hero-motif, also see Pardes, "The Biography of Ancient Israel”, 27-30.

49 The names of the women directly involved are only reported in later Jewish literature: Yochebed (Moses' mother), Miriam (Moses' sister), and Bithya (the daughter of the ruling Pharaoh). In the biblical text, they remain nameless. Cf. Frymer-Kensky, Reading the Women of the Bible; Tuchman and Rapoport, Moses' Women.

50 ESV.

51 Yee, “"Take This Child and Suckle It for Me”, 180.

52 Chapman, "Oh that you were like a brother to me", 31-32. 
In two other narratives, both of which are closely related in their content and structure, wet nurses save male figures who are to become kings of Israel. In 2 Sam 4:4, the wet nurse of Merib-Baal/Mephibosheth flees with the child after she hears of Israel being defeated at Gilboa, albeit injuring the child in the hasty escape:

Jonathan, the son of Saul, had a son who was crippled in his feet. He was five years old when the news about Saul and Jonathan came from Jezreel, and his nurse took him up and fled, and as she fled in her haste, he fell and became lame. And his name was Mephibosheth. ${ }^{53}$

Merib-Baal/Mephibosheth, the only descendent of Saul, indeed survives into adulthood and is mentioned several times in the Second Book of Samuel as being protected by the royal family. Aside from narrating an act of resistance by a wet nurse who stays close to her issue and to the royal family of Israel, the text using this motif also intends to show David's gracious acts towards possible enemies and his inclusion of them into his dominion..$^{54}$

2 Kgs 11:2 also narrates the rescue of royal offspring Joash, the young grandson of King Joram, from the dangerous actions of Queen Athaliah by the wet nurse of the child and the daughter of the king:

But Jehosheba, the daughter of King Joram, sister of Ahaziah, took Joash the son of Ahaziah and stole him away from among the king's sons who were being put to death, and she put him and his nurse in a bedroom. Thus they hid him from Athaliah, so that he was not put to death. ${ }^{55}$

Joash subsequently goes into hiding for six years and is probably assisted by his wet nurse during that time. He later becomes the rightful king of Israel, being lifted up into that position by the high priest and the army of the king and, as $2 \mathrm{Kgs} \mathrm{12:1} \mathrm{reports,} \mathrm{by} \mathrm{doing} \mathrm{what} \mathrm{was} \mathrm{right} \mathrm{in} \mathrm{the} \mathrm{eyes} \mathrm{of} \mathrm{God.}$

This last note underlines the theological thinking behind these narratives of rescue by wet nurses. In all three narratives, crucially important men in the history of Israel are saved by the courageous acts of wet nurses who resist greater powers in order to save their "milk sons" from certain death: Moses, the leader of the Exodus and the most important savior figure of what is later to become Israel; Joash, one of the men who form the line of kings of Israel; and Merib-Baal/Mephiboshet, the grandson of Saul. The men who are saved, and the divine providence that ensures that the acts of resistance carried out by women actually work, are more important than the women who save these children. Most of them remain unnamed, and only later tradition corrects this. As the women remain in the background and are not called by their actual names, human feelings such as love, kindness, or compassion, which are often connected to both breastfeeding and the act of rescuing a child, are absent from these texts. Again, this proves that narratives about wet nurses saving children are not texts describing acts of kindness, but texts that tell of acts of resistance that ensure the survival of the people Israel. The kind actions of women, human wet nurses and mothers, actually serve the theological purpose of narrators who would like to convey the early and dangerous history of a nation to their listeners and readers.

\section{Conclusion: Motherhood and Religion in the Hebrew Bible}

In religious studies, "motherhood remains a marginal topic," 56 and in gender studies, it is only now coming to the fore, having been the "unfinished business of feminism." ${ }^{57}$ This article intends to contribute to this process by outlining how motherhood and religion intermingle in the Hebrew Bible, what one

53 ESV.

54 Cf. Frymer-Kensky, Reading the Women of the Bible, 141.

55 ESV. Also 2 Chr 22:11 (ESV): "But Jehoshabeath, the daughter of the king, took Joash the son of Ahaziah and stole him away from among the kings sons who were about to be put to death, and she put him and his nurse in a bedroom. Thus Jehoshabeath, the daughter of King Jehoram and wife of Jehoiada the priest, because she was a sister of Ahaziah, hid him from Athaliah so that she did not put him to death."

56 Guignard and Pedrucci, "Motherhood(s) and Polytheisms”, 406.

57 O’Reilly, Matricentric Feminism, 2. 
can learn about the authors' ideas of motherhood and the purposes for which they used the metaphor of motherhood.

As we have seen in all of the instances mentioned, actions connected to motherhood, such as conception, pregnancy, birth, breastfeeding, and the rearing of children during early infancy, are not told by the Hebrew Bible in order to provide insight into human life. While some information about the lives of women can certainly be gained through these texts, they first and foremost serve a literary and theological purpose, namely the purpose of narrating the early history of the people of Israel as they develop into a nation. The individual women, their feelings, emotions, and characteristics, are thus used by the biblical texts in order to convey a message about the Jewish religion rather than a message about human beings and their daily cares. This, by the way, is one of the reasons why the language of giving birth and of breastfeeding is easily applied to males in the Hebrew Bible, either in the cases of men behaving like women giving birth during times of crisis or in cases of God behaving like a woman giving birth (Isa 42:10-17) or like a caring and nourishing or even breastfeeding mother (Num 11:12; Deu 32:13; Isa 66:11-13; possibly also Gen 49:25 and Hos 11:4). As motherhood intermingles with religion, it is extended beyond the female part of humanity and can also be applied to males and to God.

Motherhood and religion are closely interwoven in the Hebrew Bible. In the narratives about the difficulties in regard to conception and birth, it is not the individual destinies of mothers and families that are the main concerns of the authors. Instead, it is the narration of the divine support for the benefit of the early ancestry of Israel. In the narratives that mention breastfeeding, it is not the tender care displayed by mothers and wet nurses towards their issues that are the main focus of the texts. Rather, breastmilk pours identity into children, and outside influences are kept away from them so that the ancestors of Israel grow up unadulterated and safe from outside dangers. The authors of these texts thus ensure that the reader realizes both the divine intervention and grace when it comes to the birth of the nation and the pure ancestry that formed the nation of Israel. ${ }^{58}$ Both the divine actions and the assurance that the roots of Israel remained unadulterated are facts that strengthened the identity of the Jewish reader past and present. They make the claim that God cared for God's people in the past, the present, and future more visible and understandable, as it connects to real people and real lives on the basis of the narratives.

In that sense, the Hebrew Bible distinguishes between "mothering" (the biological functions of women and parents) and "motherhood" (as in "the institution of motherhood"), as a whole making sure that any narratives of mothering actions by women, such as conceiving, being pregnant, giving birth, and caring for a child, are set in the context of "motherhood," of God causing Israel to be born. Even the behavior of men in crisis, which is often likened to the behavior of women giving birth, might be "mothering"-like at first glance but, in the end, serves "motherhood" in that it is set within the context of Israel defending itself and gaining strength as it grows into a nation..$^{59}$

If one defines the status of being a mother as consisting of preservation, growth, and social acceptance as Sara Ruddick as done, ${ }^{60}$ the concept of motherhood is an ideal one to be employed by the authors of the Hebrew Bible to describe divine activity. The narratives of the delayed or difficult conception of the ancestors of Israel and of the birth of these important figures in the book of Genesis show how divine influence ensures the early growth of the people. The narratives about breastfeeding and the saving actions of the mothers and wet nurses in turn prove that the deity again uses human hands and human acts of resistance in order to preserve the ancestors and important male figures of Israel, and to promote the growth of a nation. The narratives also deal with the question of social acceptance. As these male figures who

58 On biblical birth stories and national identity, also see Pardes, “The Biography of Ancient Israel”, 35-36.

59 Cf. the distinction in Rich, Of Woman Born, 13: “... two meanings of motherhood, one superimposed on the other: the potential relationship of any woman to her powers of reproduction and to children; and the institution, which aims at ensuring that that potential - and all women - shall remain under male control.” The distinction is also made by Guignard and Pedrucci, "Motherhood(s) and Polytheisms", 409.

60 Ruddick, Maternal Thinking, esp. on pg. 17: "These three demands - for preservation, growth, and social acceptability constitute maternal work, to be a mother is to be committed to meeting these demands by works of preservative love, nurturance, and training." 
will become important for the history of Israel are delivered and raised by their Israelite mothers, they are infused with values that the authors of the Hebrew Bible considered to be important in the past, present, and future search for Jewish identity. Outside or foreign influences are minimized in these narratives as mothers and wet nurses appropriate the religious convictions of the authors of these texts into their own actions.

Thus, the relationship between motherhood and religion is a two-way street in the Hebrew Bible. On the one hand, religious convictions by the authors of these texts clearly shape the narratives that - at first glance appear to be only about women, children, and families. The authors' theologies form the narratives about mothers and children by determining the actions of the human beings involved. On the other hand, when one looks at these texts again, one might get a few glances at the fact that the religion, which would later become Judaism, was deeply influenced by the characteristics that are usually attributed to motherhood. This becomes most visible and most notable in the character traits attributed to the God of Israel, who brings the people into life, feeds them, cares for them, and helps them develop an identity.

\section{References}

Bergmann, Claudia D. "Turning Birth into Theology: Traces of Ancient Obstetric Knowledge within Narratives of Difficult Childbirth in the Hebrew Bible." In Children in the Bible and the Ancient World. Comparative and Historical Methods in Reading Ancient Children, Shawn W. Flynn (ed.). Routledge, 2019, 17-34.

Bergmann, Claudia D. ''Like a Warrior’ and 'Like a Woman Giving Birth': Expressing Divine Immanence and Transcendence in Isaiah 42:10-17." In Bodies, Embodiment, and Theology of the Hebrew Bible, S. Tamar Kamionkowski and Wonil Kim (eds.). New York: T\&T Clark, 2010, 38-56.

Bergmann, Claudia D. Childbirth as a Metaphor for Crisis: Evidence form the Ancient Near East, the Hebrew Bible, and 1QH XI,1-18 (BZAW 382). Berlin, New York: Walter de Gruyter, 2008.

Binder, G. "Geburt II (religionsgeschichtlich)." Reallexikon für Antike und Christentum. T. Kluser et al (eds.). Stuttgart: Anton Hiersemann (1976), 9:43-171.

Chapman, Cynthia R. “'Oh that you were like a brother to me, one who had nursed at my mother's breast.' Breast Milk as Kinship-Forging Substance." Journal of Hebrew Scriptures 12 (2012): 1-40.

Chodorow, Nancy. The Reproduction of Mothering Psychoanalysis and the Sociology of Gender. University of California Press, 1999. Conrad, J. "Kashar”. In Theological Dictionary of the Old Testament. G. Johannes Botterweck and Helmer Ringren (eds.). Grand Rapids, Michigan: William B. Eerdmans Publishing Company (2004), XIII: 196-201.

Fildes, Valerie. Wet-Nursing: A History from Antiquity to the Present. Oxford: Basil Blackwell, 1988.

Finsterbusch, Karin. “Geburt (AT)”. url: https://www.bibelwissenschaft.de/wibilex/das-bibellexikon/lexikon/sachwort/ anzeigen/details/geburtat/ch/827592ce25af60da6896bb312402a1ed/ [accessed: 03.09.2019].

Frymer-Kensky, Tikva. Studies in Bible and Feminist Criticism. Philadelphia: The Jewish Publication Society, 2006.

Frymer-Kensky, Tikva. Reading the Women of the Bible. New York: Schocken Books, 2002.

Frymer-Kensky, Tikva. Motherprayer. A Pregnant Woman's Spiritual Companion. New York: Riverhead Books, 1995.

Frymer-Kensky, Tikva. In the Wake of the Goddesses: Women, Culture and the Biblical Transformation of Pagan Myth. New York: Fawcett Columbine, 1992.

Garroway, Kristine Hendricksen. Growing Up in Ancient Israel. Children in Material Culture and Biblical Texts. Atlanta: SBL Press, 2018.

Gruber, Mayer I. "Breast-Feeding Practices in Biblical Israel and in Old Babylonian Mesopotamia." Journal of the Ancient Near Eastern Society 19 (1989): 61-83.

Guignard, Florence Pasche and Giulia Pedrucci. “Motherhood(s) and Polytheisms: Epistemological and Methodological Reflections on the Study of Religions, Gender, and Women”. Numen 65 (2018), 405-435.

Haskell, Ellen Davina. Suckling at my Mother's Breast. The Image of a Nursing God in Jewish Mysticism. SUNY Series in Western Esoteric Traditions. State University of New York Press, 2012.

Marsman, Hennie J. Women in Ugarit and Israel. Leiden: Brill, 2003.

Holtz, Gudrun. Jungfrauengeburt und Greisinnengeburt. Zur Rezeptionsgeschichte von Gen 21,1f im antiken Judentum und im frühen Christentum. Vandenhoeck \& Ruprecht, 2017.

Hrdy, Sarah Blaffer. Mother Nature: A History of Mothers, Infants, and Natural Selection. New York: Pantheon Books, 1999.

Kunz, Andreas. "Die Vorstellung von Zeugung und Schwangerschaft im antiken Israel“. ZAW 111 (1999): 561-582

Kunz-Lübcke, Andreas. "Schwangerschaft“, url: https://www.bibelwissenschaft.de/wibilex/das-bibellexikon/lexikon/ sachwort/anzeigen/details/schwangerschaft/ch/de48d0fe35684b3a1da6d0fd78de5dc2/ [accessed: 03.09.2019].

Maher, Vanessa. The Anthropology of Breast-Feeding: Natural Law or Social Construct. Oxford: Berg, 1995. 
Meyers, Carol. Discovering Eve: Ancient Israelite Women in Context. New York: Oxford University Press, 1988.

O’Reilly, Andrea. Matricentric Feminism: Theory, Activism, and Practice. Bradford: Demeter Press, 2016.

Pardes, Ilana. "The Biography of Ancient Israel: Imagining the Birth of a Nation”. Comparative Literature 49 (1997), 24-41.

Preuss, H.B. "Yatsa”. In Theological Dictionary of the Old Testament. G. Johannes Botterweck and Helmer Ringren (eds.).

Grand Rapids, Michigan: William B. Eerdmans Publishing Company (1990), VI: 225-250.

Rich, Adrienne. Of Woman Born. Motherhood as Experience and Institution. W.W.Norton Company, 1995.

Ruddick, Sara. Maternal Thinking: Toward a Politics of Peace. Beacon Press, 1989.

Salm, Eva. Juda und Tamar: Eine exegetische Studie zu Gen 38. WüNewrzburg: Echter Verlag, 1993.

Smith, D. Charles. The Role of Mothers in the Genealogical Lists of Jacob's Sons. Contributions to Biblical Exegesis and Theology 90. Leuven: Peeters, 2018.

Spitzer, Beatrix. Der zweiter Rosengarten. Eine Geschichte der Geburt. Hannover: Elwin Staude Verlag, 1999.

Stol, Marten. Birth in Babylonia and the Bible. Its Mediterranean Setting. GroNewningen: Styx Publications, 2000.

Tuchman, Shera Aranoff, and Sandra E. Rapoport. Moses' Women. Jersey City, NJ: KTAV, 2008.

Winter, Urs. Frau und Göttin: Exegetentische und ikonographische Studien zum weiblichen Gottesbild im alten Israel und dessen Umgebung. Freiburg: Universitätsverlag Freiburg, 1983.

Yee, Gale A. “'Take This Child and Suckle It for Me': Wet Nurses and Resistance in Ancient Israel.” Biblical Theology Bulletin 39 (2009): 180-89. 